Tom LXXVII - 2016 (specjalny)

\begin{tabular}{llllllll}
\hline $\mathrm{A}$ & $\mathrm{R}$ & $\mathrm{T}$ & $\mathrm{Y}$ & $\mathrm{K}$ & $\mathrm{U}$ & $\mathrm{E}$ & $\mathrm{Y}$
\end{tabular}

ZDZISŁAW NOGA

Uniwersytet Pedagogiczny w Krakowie

RYSZARD SZCZYGIEE

Uniwersytet Marii Curie-Skłodowskiej w Lublinie

\title{
MIASTA PRYWATNE W SIECI MIEJSKIEJ KRÓLESTWA POLSKIEGO I RZECZYPOSPOLITEJ OBOJGA NARODÓW. UWAGI WSTĘPNE
}

Miasta istniejące na terytorium Królestwa Polskiego i Rzeczypospolitej Obojga Narodów znajdowały się w dobrach różnych własności. Były więc miast królewskie $\mathrm{w}$ dobrach domeny monarszej, miasta kościelne w majątkach klasztorów i biskupstw oraz miasta w dobrach rycerskich (szlacheckich) i możnowładczych (magnackich). Wszystkie one powstały w następstwie ruchu lokacyjnego na prawie niemieckim, jaki rozpoczął się na ziemiach polskich w XIII w. i trwał z różnym natężeniem do XVIII w., wykazujac odmienności regionalne. Ośrodki miejskie w dobrach kościelnych i feudałów świeckich zwykliśmy nazywać miastami prywatnymi.

Przyjmuje się w naszej historiografii, że na zachodnich i centralnych ziemiach Królestwa Polskiego do końca średniowiecza ukształtowały się zasadnicze zręby sieci miejskiej. Dotyczy to przede wszystkim miast królewskich. Od XVI w. urbanizacja według modelu miasta lokacyjnego we wszystkich rodzajach własności rozwijała się intensywnie na terenach: Rusi Czerwonej, Podola, Wołynia i dalszej Ukrainy. $\mathrm{W}$ następstwie tego procesu powstała sieć miejska obejmująca miasta różnej wielkości i znaczenia oraz zasięgu oddziaływania, dla których wspólne było miejskie prawo niemieckie.

$\mathrm{Na}$ terytorium całego państwa dominowały w czasach wczesnonowożytnych lokacje miast prywatnych. Wiązało się to z przeobrażeniami gospodarczymi i zmianami w społecznym podziale pracy, będącymi następstwem rozwoju folwarku pańszczyźnianego, a także ze zmianami ustrojowymi oraz wzrostem roli szlachty i magnaterii w państwie. 
Miasta prywatne rozwijały się jako gospodarcze ośrodki centralne okolicznych dóbr właściciela, pełniąc funkcje w wymianie lokalnej, ale często też dalekosiężnej, w mniejszej zaś skali będąc ośrodkami wytwórczości. Znajdowała się w nich zazwyczaj administracja dóbr, były też powiązane z rezydencjami właścicieli, stanowiąc dla nich zaplecze usługowe.

W dziedzinie prawa i ustroju miasta prywatne wzorowały się na królewskich. Były jednak w tej sferze uzależnione od decyzji właścicieli, co wiązało się z niedorozwojem samorządu miejskiego. Ograniczenia dotyczyły też w wielu przypadkach wolności osobistej mieszczan, chociaż w świetle istniejących badań zachowali ją do rozbiorów, w oparciu o przepisy prawa niemieckiego. W porównaniu z miastami królewskimi mieszczanie $\mathrm{z}$ ośrodków prywatnych obciążeni byli większymi powinnościami, niekiedy z pańszczyzną włącznie.

Miasta prywatne odgrywały ważną rolę w gospodarce, życiu społecznym i kulturze Polski czasów wczesnonowożytnych. Uwidoczniła się ona szczególnie w funkcjonowaniu dóbr ziemskich ich właścicieli, w organizacji wymiany handlowej, zwłaszcza spławu wiślanego, wreszcie $\mathrm{w}$ dziejach reformacji, życia religijnego i kultury, ze względu na wieloetniczność i wielokulturowość ich mieszkańców. Rola ta wiązała się zarówno z systemem sprawowania władzy w Rzeczypospolitej, jak i panującym ustrojem gospodarczym oraz struktura społeczną kraju.

Miały więc miasta prywatne w Polsce przedrozbiorowej swoją specyfikę i, jak się uznaje, własną drogę rozwoju. Od początku lat 50. ubiegłego stulecia stanowią odrębny przedmiot badań‥ W 1974 r. Andrzej Wyrobisz podjął próbę ukazania ich roli w dziejach Polski w XVI i XVII w. Podsumował stan badań oraz wysuną wiele postulatów do dalszego ich prowadzenia ${ }^{2}$. Niestety, niewiele $\mathrm{z}$ nich $\mathrm{w}$ nawiązaniu do tego kwestionariusza zostało podjętych w kolejnych badaniach.

Problematyka miast prywatnych była w ostatnich latach zaniedbywana przez historyków. Pomimo obszernej bibliografii obserwujemy rozproszenie celów badawczych, gdyż sytuują się one na pograniczu pól badawczych różnych specjalności historycznych: historii gospodarczej, społecznej oraz badania elit, historii kultury, urbanistyki i architektury, wreszcie historii ustroju. Stan badań nad dziejami miast prywatnych jest więc trudny do oceny. Uwaga ta w mniejszym stopniu dotyczy

${ }^{1}$ Zob. W. Sobociński, Z badań nad miastami prywatnymi w Polsce, CPH, t. 7, 1955, z. 2, s. 130-311; J. Mazurkiewicz, O niektórych problemach prawno-ustrojowych, miast prywatnych w dawnej Polsce, „Annales UMCS”, sectio G, Ius, t. 11, 1964, s. 98-101.

2 A. Wyrobisz, Rola miast prywatnych $w$ Polsce $w$ XVI $i$ XVII wieku, PH, t. 65, 1974 , z. 1 , s. $19-46$. 
monografii poszczególnych miast, jakie licznie ukazywały się w ostatnich dziesięcioleciach. Mają one jednak różną wartość naukowa, niektóre zawieraja nawet treści nie zawsze zgodne $\mathrm{z}$ aktualnych stanem badań.

Dlatego Zespół Historii Miast przy Komitecie Nauk Historycznych PAN podją tę problematykę, zakładając, że plonem konferencji będzie podsumowanie dotychczasowego stanu badań, ale także wytyczenie kierunków dalszego ich prowadzenia. Autorzy podjęli problematykę miast prywatnych z perspektywy dzielnic historycznych (Małopolska, Wielkopolska, Ślask, ziemie wschodnie Rzeczypospolitej), a także w szerszym zakresie przestrzennym przez pryzmat poszczególnych zagadnień (struktury demograficzne i społeczne, sądownictwo, reformacja, ludność żydowska). Warto tu podkreślić, że podjęto pierwszą w historiografii próbę policzenia miast prywatnych realnie funkcjonujących, a nie tylko lokowanych. Poruszone kwestie nie wyczerpuja oczywiście tego interesującego i wciąż nie do końca rozpoznanego obszaru badawczego. Winny jednak stanowić impuls do dalszych studiów, w tym nad rola gospodarczą miast prywatnych, zakresem wolności mieszczan, strukturą demograficzną i mobilnością społeczna, opieką społeczną i szkolnictwem, wreszcie nad ich rolą kulturalną.

Obrady konferencji, z której poszerzone i uzupełnione wystapienia znalazły się z niniejszym tomie, toczyły się 23-24 kwietnia $2015 \mathrm{r}$. w Zamościu, w mieście uznanym zgodnie przez historyków i urbanistów za wyjątkowe w skali europejskiej. Nazywa się je nawet miastem idealnym. Wyjątkowość tego ośrodka wiązała się przede wszystkim z planem przestrzennym, nawiązującym do najdoskonalszych osiagnięć włoskiej myśli urbanistycznej późnego renesansu, oraz z realizacją tej koncepcji. Jest to do dzisiaj jeden z najciekawszych zespołów urbanistyczno-architektonicznych powstałych na ziemiach polskich $\mathrm{w}$ dobie renesansu, a także jedna $\mathrm{z}$ niewielu tak udanych lokacji miasta prywatnego w Rzeczypospolitej wczesnonowożytnej. 